\title{
Treatment of the Race-Consciousness in Ralph Ellison's Invisible Man
}

\author{
Munther Mohd. Habib ${ }^{1}$ \\ ${ }^{1}$ Department of English Language, Literature and Translation, Zarqa University, Zarqa, Jordan \\ Correspondence: Professor Munther Mohd. Habib, Department of English Language, Literature and Translation, Zarqa \\ University, Zarqa, Jordan.
}

Received: September 14, 2017

Accepted: October 7, 2017 Online Published: December 27, 2017

doi:10.5539/ass.v14n1p48

URL: https://doi.org/10.5539/ass.v14n1p48

This research is funded by the Deanship of Scientific Research at Zarqa University-Jordan

\begin{abstract}
Ralph Ellison's Invisible Man portrays the plight of 'blacks' in America and is a testimony to the fact that the negroes feel disillusioned in a world which is dominated by the white oppressors. Moreover, it is my assertion in the paper that the journey of the un-named hero is a journey from innocence to awareness. The protagonist at the end comes to realize the duplicity of the whites and through his experiences has been successful to convey his individuality.
\end{abstract}

Keywords: Race-consciousness, violence, discontent, identity, individuality, universal man, journey, awareness, freedom

\section{Introduction}

The burden of race-consciousness has been an unavoidable lot of the Blacks ever since they were brought as slaves of the USA. Even after emancipation, they continue to suffer the ignominies of their white masters. This has not only contributed to violence and discontent in the country, but has been also distorted both the whites and the blacks. For the latter, it has meant both a most formidable challenge and any excuse for addiction to "self-pity, anxiety and psychological dependence." ${ }^{1}$

In any case, the result is that every Negro in America continues to carry all through his life the burden of race-consciousness like a corpse on his black. The impact of slavery has been most debilitating. Many a Black feels inferior because he repeatedly told that he is inferior; most turn self-defensive and aggressive in their assertions of their superiority. The distorted system yields the Blacks "no true self-consciousness." They always look at themselves with the eyes of the whites look at themselves as if they were their own other: "One ever feels his two-ness-an American, a Negro; two souls, two thoughts, two unreconciled strivings; two warring ideals in one dark body, whose dogged strength alone keeps it from being torn asunder." ${ }^{2}$ This "consciousness of ambiguity" ${ }^{3}$ finds its expression in Ellison's unnamed narrator - hero in Invisible Man whose journey from the south to the north becomes "a journey into the self ${ }^{4}$ or "quest for identity ... an epic journey through a labyrinth of freedom, conformity, denial and possibility. ${ }^{5 "}$

Ellison's reaction to the type of criticism that treats the protagonist of the novel as representative of a universal man is noteworthy. In a letter addressed to James Alan McPherson Ellison says: "So many concerned blacks had read the plight of the Afro-American into this figure with no face and no name. So many people saw the author riding a champion the cause of the black man. Those same people heard him say that the symbol was representative of universal man. I found the most disheartening, ${ }^{16}$ therefore, in view of the aforesaid evidence, it is difficult to believe in the statements which attempt at highlighting the universal overtones of the novel. Indeed. That seems to be a way to undermine the main thrust of the book, which is surely intended by Ellison to serve as an eye-opener to not only the white oppressors the Uncle Toms as well.

In fact, the critics' attempts to attribute universal dimension to the novel by equating the protagonist the "No man and Everyman" seem to be intriguing as these epithets do not lead the reader to the heart of the matter which lies in Ellison's attempt at self-definition as the American-Negro has been "misnamed by others" ${ }^{7}$ Viewed from the perspective of black experience, the novel testifies to the fact of discrimination of the blacks by the whites on the basis of color. It articulates the predicament, the dilemma of Negro who find themselves disillusioned in the sham world of white oppressors. Far from seeking to universalize, the phenomenon of exploitation of the black by the white, Ellison's novels an attempt at self-definition. It can be viewed as Ellison's attempt to deifier and assert his racial identity. "At a time when many blacks, especially the young, are denying all influences of American culture, Ellison as always, 
doggedly affirms his identity as Negro-American, a product of the blending of both cultures. But more than this, he attempts to explore most of complex implications of this burden in his fiction, in his essays, speeches, and his private life ... he is thinking Blackman who has integrated his homework into the fabrics of his private life." ${ }^{8}$ Thus in considering himself as "a product of the blending of both cultures" - the black as well as the American - Ellison does not recognize any "American culture which is not the partial creation of black people" ${ }^{9}$. The novel is, thus, an attempt to "assert his own individuality in his own terms" ${ }^{10}$ by challenging the defence mechanisms of the black community. In the process, his journey becomes a journey from innocence to awareness, a journey which enables him to see through the duplicity of the white oppressors.

Thus, the racial journey not only enables him to make himself visible to the Nortons and the Bledsoes, but also serves as an eye-opener to the teeming millions of his race who will be compelled to undertake a similar journey in terms of racial consciousness. He is determined to break the myth of the monopoly of the whites on individuality and intelligence by exposing the whites as well as the Uncle Toms, who want to perpetuate the myth.

\section{Discussion}

The novel opens in a South American town in the first half of the twentieth century. Written in a retrospective first-person narrative like Moby Dick and The Great Gatsby, the novel recounts the happenings from the time of the narrator's graduation from high school to the point at which he began to live underground - "a critical period of development that encompasses his right of passage from adolescence to the threshold of maturity." ${ }^{11}$

The speech the narrator delivers at his high school valedictory function in so impressive that he invited to deliver it again before the most prominent white citizens of this Southern town. Although he is invited to deliver a speech at a leading hotel in the town, yet it is given a very low priority. Instead he and group of his schoolmates are huddled on the stage and asked to wear boxing gloves. As they prepare themselves to fight the Battle Royal, a stark-naked blonde dances on the stage. They are forced to look at her and threatened if they do not. They are blindfolded and commanded to box with each other. Fake coins are thrown on the electrified carpet as payment. When they try to pick up the coins, they receive shocks.

The narrator is exposed to a fake world presented to him in the Battle Royal scene. Fake coins on the electrified rug seem to be suggestive of the extent to which the blacks have been driven by their white oppressors. The coins are emblematic of the identity, the only one that the whites can afford to confer on the narrator. Needless to add, this identity presupposes psychological dependence on the white masters. Even through the coins are fake .the narrator's attempts culminate in electric shocks that he receives in the process. However, at this stage, the narrator is too naïve to realize the implications as the truth in known to the whites only. The suggestion is that the type of identity that the whites want the narrator to have, is fake like the coins as the narrator will not be allowed to transcend the barriers which block the way on his racial journey. He is supposed to follow in the footsteps of his grandfather, to "overcome" them with yeses."12 But at this stage, he is unable to understand the true significance of the death-bed advice of his grandfather. It is only towards the end that the narrator will be able to see possible hidden meanings in this exhortation.

Finally, the narrator is asked to give his speech to the jeering audience. He temporarily upsets his listeners by saying 'equality' while he had intended to say 'responsibility.' An instant explosive reaction from the whites forces him to recant the words. Gloating over his surrender, he is given a scholarship to the local college for black, along with a calf-skin brief case which contains a document with the following recommendation: "keep This Nigger-Boy, Running" (p.32).

The scene proves to be a "crucial initiatory experience"13 of the hero's boyhood. His briefcase carries the reward, a scholarship which is supposed to open a new world of experience to him, and a world which will enable him to penetrate beneath the surface of the white reality. However, as the future course of events unfolds, the briefcase turns out to be a repository only of the symbols of his disillusionment and remind one of S.T Coleridge's 'albatross' which the unnamed narrator carries around his neck while charting the course of his perilous journey.

The Battle Royal scene is a glaring example f oppression and self-victimization. George E. Kent aptly puts it: "On the level of Blackness, there is the manipulation of Blacks to fight each other blindly, education as brainwash, the general white manipulation of reality, and the shaping of misleaders of the people." ${ }^{\prime 4}$ Here, it would be pertinent to recall that the protagonist is blind to his own plight and the miseries happed on him by the Whites. He thinks that education will free him from the shackles of white oppression and help him realize his cherished goal of individual identity in a democratic society which echoes Ellison's eventual concern and can be traced back to his “father's gesture of naming him Ralph Waldo in honor of Emerson." 15 As the novel progresses, one comes to realize the futility of the hero's successive attempts at seeking some sort of identity, but his individuality is ignored both by the blacks and whites. However, it is his invisibility which endows him with a better sight, a wider perspective. Ellin Horowitz is right when he finds a method in this invisibility. He observes, “The hero's invisibility is like Hamlet's madness: it is both a plight 
and a device." ${ }^{\prime 16}$ Perhaps, like Louis Armstrong, he is bent upon making poetry "out of being invisible” (p.11).

The anguish and frustration of the protagonist is manifest here. His innocence is abused by a fellow Black who does not mind being a puppet in the hands of his white masters as long as his own position is secure. The protagonist is admonished as he has failed to learn the tactics of telling lies to please the white, forfeiting, thus the very purpose of education he is getting at the college. It is a system of education which is designed to keep the Negroes in their place by encouraging racial discrimination. He is expelled from the college. In the seemingly kind gesture, the hero is given letters of introduction to influential men in New York may be helpful in getting him a job. Here, Ellison also suggests the moral deprivation of the whites who are in no way superior to the blacks. The unnamed narrator has tried to assess his individuality and sees no point in "yessing" the whites. Animal instincts are a part as much of the life of the whit as that of the blacks. The Golden Day episode further establishes that "animality" is part of the human condition." 17 In the process, Dr. Bledsoe, instead of helping the protagonist, confuses him and clouds his vision which not only results in his expulsion from the college but opens him to a new world of experience in New York and marks a significant in his quest for racial awareness.

The hero comes to discover that Dr. Bledsoe has betrayed him. In fact, the letters are only the criticism of the 'invisible man' as these prove to be the variations of the letter his grandfather showed him in a dream. These are only betrayals as there is no prospect of his ever coming back to the college. Even the letter to Emerson, in essence, says: "Keep this Nigger-Boy Running," This is a cruel and practical joke on the blacks and relates to the times of slavery, when illiterate blacks required a note signed by the white master to enable them to travel from plantation to plantation. But here, the narrator is made to run in vain from one place to another by not only the white Master but a caucus of people who include those of his own race. As the narrator progresses on his racial journey, his destination eludes him like a horizon that recedes farther as he seems to approach it. It is only after realization of the real import of the letter that awareness will come to him. So far his journey has led him only from one disillusionment to another as the college has proved no better than his experience in the Battle Royal. In the hope of becoming a teacher or a member of the administrative staff he has been duped by the Nortons and the Bledsoes into believing that they are his benefactors. Deceived and disillusioned, he keeps running from one to another.

Earlier, in the Battle Royal scene he was deceived by only the whites, but now realizes that even the blacks, his own people, are in league with the whites for their self-interest. He realizes that the deceit and duplicity of his own men has been the root cause of his expulsion from Eden. He becomes aware or the powerful coalition of Bledsoe and Norton. He understands that his struggle from now onwards is both with the blacks as well as the whites.

In fact, Bledsoe's letter to Emerson serves as an eye-opener to the protagonist. His mind flows in circles at the revelation that he will never be allowed to return to the college. Determined to avenge his hurt and humiliation he asserts: "I decided that I would go back and kill Bledsoe. Yes .I thought, I owe it to race and to myself .I'll kill him" (p.159).Thus, the narrator is devoted to the cause of his race .To ameliorate the lot of his community, he will have to fight the Bledsoe and his own people.

Unable to find a suitable education, he takes up a job in a paint factory. There he works under Luscious Brockway who considers this educated Negro a threat as he does not know this place and might offended the white masters. This Uncle Tom has created the company slogan: "If it's Optic White. It's the Right white" (p.177) for which he got a three hundred dollar bonus from the factory owners .The protagonist's recollection of a childhood jingle, "if you're white, you're right" (p.178) betrays his keen perception of the white duplicity which cannot allow independent thinking by the blacks. This denial of individuality certainly comes in the way of racial upliftment. Moreover; this attitude of the whites to negate the contribution of the blacks to the American idustrialisation also speaks of the racial discrimination which is sought to be perpetuated endlessly. However, the hero has begun to see through the machinations of the white masters, which marks a significant step in his racial awareness. The hero's unconscious inability to make white paint, only speaks of his implicit rebellion against Lucius Brockway whose security of job is in danger, but also poses a challenge to the white supremacy.

His first act of rebellion is followed by the furnace explosion which lands him in the factory hospital. There he sees strange visions of birth with suggestions of lobotomy and castration. Ellin Horowitz aptly sums up the ordeal of the hero: "...'delivery' is complete with the literal cutting of an umbilical cord. The personality is dead and the initiate has a new identity born out of the machine. Because he has lost his past he is considered cured but when questioned about Buckeye the Rabbit he remembers playing this part as child and is brought back through reversion to the folk tradition of which he is an unacknowledged part."18

Thus, the hero's traumatic experience in the furnace explosion may be interpreted as his spiritual death and his simultaneous rebirth. It is the death of his old self. He knows that freedom and identity are one. When he is free, he will have his individual identity. The narrator-protagonist's rumination poignantly suggests his keen self awakening: 
I wanted freedom, not destruction. It was exhausting, for no matter what the scheme I conceived, there was one constant flaw-myself. There was no getting around it. I could no more escape than I could think of my identity. Perhaps, I thought, the two things are involved with each other. When I discover who I am, I'll be free (p.198).

Thus he rejects Lucius Brockway, a Negro himself, who wishes to ensure his own security even at the expense of other Negroes. He realizes that identity and freedom are synonymous and complementary to each other. For his proper development the 'Invisible Man' needs to reject these anti-life forces.

This is a crucial stage in the protagonist's journey of racial consciousness as this experience in the factory hospital has the semblance of the phase of passage though inferno. He becomes completely oblivious of his past. In the words of Ellin Horowitz:"...he is like a child, without a past, helpless, and lost in a "vast whiteness." ${ }^{19}$ He is ill, weakened, and friendless. It is at this stage during his racial journey that he comes in the care of Mary, a motherly woman. He thinks of her as "a force, a stable, familiar force like something out of my past" ( $p, 210)$ which is representative of the protagonist's southern roots. She reminds him of his past and demands a credit to the race. Later on, under the benign motherly influence of Mary, he accepts Negro food. He eats yams on the streets. This boldness on his part constitutes a landmark in his racial journey as this "act of participating in and enjoying an element of his heritage has given him his freedom." ${ }^{, 20}$ His exhilaration is noteworthy: "I walked along, munching the yam, just as suddenly overcome by an intense feeling of freedom-simply because I was eating while walking along the street" (p.214). He can proudly say: I yam what I am" (p.215).

This playing with the language links him with his past, his history, his very identity, and becomes his passport to the 'Brotherhood', "a fictional representation of the Communist party." ${ }^{21}$ It is this spirited acceptance of his roots that inspires to deliver the eviction speech. Ultimately, it is this deep sense of his racial and familial past that wins him a position in the 'Brotherhood', where he studies ideology with Brother Hambro.

The protagonist's growing sense of self-awareness is obvious in his Harlem speech. With his improved vision, he is able to see through the thick haze of history and is determined to break the shackles of age-old oppression. His clarity of vision enables him to foresee a speedy end to the "uncommonly blind journey" of his people. It is this sense of awareness which leads him towards the wholeness of his being. Conscious of his individuality, he will, no more be duped by those who refuse to see him. However, at this stage, the narrator is least aware of the designs of the 'Brotherhood'.

It is only when the protagonist realizes that the 'Brotherhood' is "a matter of sacrificing the weak" (p. 407), he begins to accept his past. He decides to translate his grandfather's advice into action by overcoming "them with yeses" (p. 409). He has certainly come a long way in his arduous journey. He understands that a definite identity is still a distant dream and that what he can at best is to recognize his invisibility. He knows fully well that he is simply a material, a natural resource to be used.

Now, the protagonist has been graduated into looking beneath the surface. His power of perception and keen observation bring about a transformation in him. He can discriminate the real from the fake and knows the truth behind tile masks. The reality of his "benefactors" becomes available to him. He realizes that the 'Brotherhood', "as much as any other group of whites. Is in a conspiracy to keep the blacks out of history."22

In the coal cellar the hero is able to get rid of the contents of his brief case. He burns his high school diploma, the threatening letter written by Brother Jack, his 'Brotherhood' name and identity, the scholarship, the letter that kept him running, the dancing doll, Brother Tarp's chain-all token of his identity.

Several emblems which the hero carries on his racial journey serve as homelier reminders of his heritage, his past which needs to be integrated into personality to move towards racial awareness. By invoking thus the history of oppression, he wants his people to remember their past. The cast-iron figure of a Negro and the paper dancing doll, among other things, in the briefcase are the reminders of his shameful past, and the hero's guilt lies in the realization that he has yet to free himself from the dismal past. While his breaking of the cast-iron figure into garments speaks of his resolve to transcend the barriers raised by the history of oppression, his carrying of the fragments is emblematic of his guilt. In fact, he emphasizes the need for his people to link themselves with their past heritage which alone can give them an awareness which will ultimately lead them to achieve racial identity. In a world characterized by white duplicity, it is essential for the Negro to go to his roots, and this possible only by embracing his past.

One cannot think when one is too much in movement; for thinking, solitude is needed. Thus the 'Invisible Man' has come to a man-hole he is hibernating, something which symbolically means returning to the reflective centers. He is going to seek out and to reflect. He has realized that he is not going to be Uncle Tom, nor is he going to be a Bledsoe or a Rosenblatt. Having been disappointed in his experiences in both the groups, black and white, he starts grappling with his individuality. 
Towards the end of the novel, the narrator-protagonist fully accepts the fact of his invisibility. Rosenblatt feels that the protagonist ends as an illusion. Charting the course of the hero's journey, he says:

The hero progresses from South to North to nothing; from capitalism to communism to nihilism. He makes a long and arduous pilgrimage which finishes in a basement; he starts Out heading for the future, and settles down in the nineteenth to those who cannot see him, and in addressing his narrative to white people explaining himself to those who made him, or to wish him to remain, inexplicable. ${ }^{23}$

Richard D. Lehan says that the "end of the novel is the beginning for both Ellison and his hero-it brings his hero an awareness of who he is not." 24 though the novel ends here, it is the real starting point in his life.

And now 1 realized as follows:

I could approach it only from the outside, and I had as invisible as I had been to the Brotherhood. No, I couldn't return to Mary's or to the campus, or to the Brotherhood, I could only move ahead or stay here, underground. So I would stay here until I was chased out. Here, at least I could try to think out in peace, or if not in peace, in quiet. I would take up residence underground. The end was in the beginning (p. 460).

The novel relies heavily on the symbolism of vision closely related to the complex problem of identity. The protagonist of Elision's novel is invisible because people refuse to see him. They see everything, except him. These people are note people of his race; they are the whites with a defective inner vision, the people who refuse to see him, to recognize his existence per se. in the process, invisibility becomes a metaphor for identity.

The protagonist has been made to think that he is getting the right kind of education at college. He sincerely pursues his studies to be a model student. However, his expulsion from the college convinces him that this education is not going to help him find his identity. It is through his education that he loses his only identity. At this stage of his career, he is not able to see beneath the surface. He remains baffled by the action of his peers who are there to ensure the perpetration of the whites' atrocities on the blacks. It is not only the whites who cheat him; indeed, even the blacks seem to be in league with the white oppressors. Significantly, before he leaves the college, the hero is asked to listen to the sermon by blind Negro, whose speech symbolically hints at myopic vision that renders him incapable of seeing into the reality of black experience.

In New York the hero realizes the extent to which he has been cheated by the President of the College. Again in the factory hospital, the protagonist tries to recollect his name. But his memory fails him. Here his inner vision enables him to perceive that he can attain true freedom only when he is able to "know" himself. Walking through Harlem, he has a unique experience when he buys some yams from a vendor and relishes them. A unique feeling satisfaction and freedom overwhelms him. This association of the protagonist with his past will enable him to assert his individuality.

His identification with the "professed" cause of the 'Brotherhood' and the applause he receives from the audience in Harlem is in sharp contrast to his traumatic experience at the hands of the jeering audience of the Battle Royal scene in the beginning of the novel. Now, he asserts himself and is determined to see that opportunities for Negroes are not restricted by their racial identity. He addresses the audience: "With your eyes upon me I feel that I've found my true family! My true people! My true country! I am a new citizen of the country of your vision, a native of your fraternal land"

He further exhorts his listeners by addressing them as "True Patriots" (p. 280) and visualizes a future world where "WE'LL BE DISPOSSESSED NO MORE!" (p. 280). Initially, he does not perceive the whole truth about 'Brotherhood', but gradually he is left with his illusion about the group's ideology. When riots take place in Harlem, the protagonist severs his connection with the 'Brotherhood'. He has been through the cunning plans of the organization and will be duped no more.

However, as Ellison explains in Shadow and Act, the hero's downward movement in the novel, literally as well as metaphorically, is paradoxically "a process of rising to an understanding of his human condilion." ${ }^{25}$ Charles I Glicksberg sees Negro's struggle to find himself, to rise to his full height as a man and achieve the glory of selfhood.",26

\section{Conclusion}

During his odyssey, the unnamed protagonist's efforts of the 'Invisible Man' to create the uncreated conscience of his race, bring credibility to the fact that he is not merely "a wounded Adam." ${ }^{27}$ His terrifying ordeal in the wood of experience has brought him close to the truth of his being. He seems, to be determined to continue his journey which will surely enable him to assert his individuality and his freedom some day and see the racial identity does not bar his way to equality with his oppressors. In the process, the novel becomes a consciousness raising exercise, a sermon for the Negro, an initiation to others undertake a similar journey in terms of racial awareness. 


\section{Notes}

1 Jayantanuja Bandyopadhayaya, North over south-A Non-Western perspective of international Relation (New Delhi: South Asian Publishers, 1982), p. 46.

2 W. E. B. DuBois, The Souls of black Folk (New York: Washington Square Press, 1970), p. 3.

3 John M. Reilly, Introduction, Twentieth Century Interpretations of Invisible Man: A Collection of Critical Essays (Englewood Cliffs, N.J.: Prentice-Hall, 1970), p.5.

4 Richard D. Lehan, “The Strange Silence of Ralph Ellison,” California English Journal, I, No.2 (1965). Pp 63-68.'rpt. in Twentieth Century Interpretation of Invisible Man, p. 107.

5 William 1. Schafer, "Ralph Ellison and the Birth of the Anti-Hero," Critique, X (1968), pp. 81-93 rpt. In John Hersey, ed. Ralph Ellison: A Collection of Critical Essays, Twentieth Century Views (Englewood Cliffs, N.J.: Prentice-Hall, 1962), p. 116.

6 James Alan McPherson, “Creating the Uncreated Features of His Face” (1970), rpt. In Reilly, pp 54-55.

7 Robert Bone, "Ralph Ellison and the Uses of Imagination”. (1966), rpt. In Reilly, p. 30.

8 James McPherson, P. 44.

9 Ibid

10 Ibid, p. 46.

11 Kerry McSweeney, Invisible Man: Race and Identity,_(Boston: Twayne Publishers, 1988): p. 28.

${ }^{12}$ Ralph Ellison, Invisible Man (1952; rpt. Harmondsworth: Penguin, 1981), p. J 7. All subsequent references are to this edition and have been incorporated in parentheses.

13 Ellin Horowitz, "The Rebirth of the Artist” (1964), rpt. In Reily, ed., p. 81.

${ }^{14}$ George E. Kent, "Ralph Ellison and Afro-American Folk and Cultural Tradition" (1970) rpt. In Hersey, ed; p,- 165.

15 John M. Reilly, "Introduction,” in John M.Reilly, p.1.

${ }^{16}$ Ian Ousby, Introduction to Fifty American Novels (London: Pan Books, 1980); p. 333.

17 M.k. Singleton, "Leadership Mirages as Antagonists in Invisible Man" (1966) rpt. In John M. Reilly, ed., p. 17.

18 Ellin Horowitz, p. 83.

19 Ibid., P. 84.

${ }^{20}$ O. Keith E. Byerman, Fingering the Jagged Grain: Tradition and Form in Recent Black Fiction. Athens: University of Georgia Press, 1985, p. 29.

${ }^{21}$ Amritjit Singh, "Racial Politics in Black American Fiction: Schuyler and Ellison." The American Political Novel: Critical Essays, ed. Harish Trivedi (New Delhi: Allied Publishers, 1984), p. 135.

22 M.L. Raina, “Black Violence: Black Despair, Richard Wiight and Ralph Ellison,” in the American Political Novel, p. 149.

${ }^{23}$ Roger Rosenblatt, Black Fiction (Cambridge: Harvard Univ, Press, 1974), p. 185.

24 Richard.D:'Lehan, p. 110.

${ }^{25}$ Lucio P. Ruotolo, Six Existential Heroes: The Politics of Faith (Cambridge: Harvard Univ. Press, 1973 ), p. 82.

${ }^{26}$ Charles I. Glicksberg," The Symbolism of Vision” (1954) rpt in John M. Reilly, Ed., p. 55.

${ }^{27}$ Nathan A. Scott, Jr., "Black, Literature," in Harvard Guide to Contemporary American Writing, ed. Daniel Hoffman (Delhi: Oxford Univ. Press. 1981), p. 297.

\section{Copyrights}

Copyright for this article is retained by the author(s), with first publication rights granted to the journal.

This is an open-access article distributed under the terms and conditions of the Creative Commons Attribution license (http://creativecommons.org/licenses/by/4.0/). 